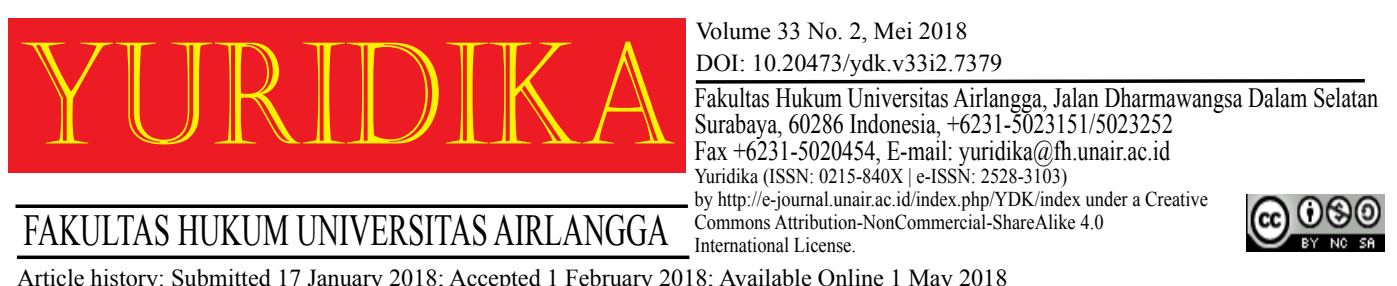

\title{
PENATAAN SISTEM PEMILIHAN UMUM YANG BERKEADILAN UNTUK PENGUATAN SISTEM PRESIDENSIIL DI INDONESIA
}

\author{
Mohammad Syaiful Aris \\ syaiful@fh.unair.ac.id \\ Universitas Airlangga
}

\begin{abstract}
Justice in election one of the constitutional mandates expressly in Article 22E Paragraph 1 of the 1945 Constitution of the State of the Republic of Indonesia. Nevertheless the Constitution does not provide further guidance on what the meaning of justice in election. Therefore, it is necessary to search philosophically what exactly the meaning of justice in the election. An alternative system is needed as a bridge between the proportional system and the district system. An alternative system must be able to create a minimum majority party in parliament to support presidential policies, improve the accountability the member of parlements and accommodate heterogeneous groups. Mixed electoral system can be considered as an alternative between the proportional system and the major (district) system by combining the virtues of each system. This system is considered fixing the main weakness of proportional system such as the creating minimal parties in parliament to support the president's policy and also improving the accountability of the people's representatives to their constituents. Furthermore, the mixed electoral system also could minimize the weakness of the majoritarian system that is the winner takes all by using the proportional system to accommodate heterogeneous and minority groups.
\end{abstract}

Keywords: Election; Justice; Presidensiil.

\begin{abstract}
Abstrak
Pemilu yang adil merupakan salah satu mandat konstitusional yang secara tegas dimuat dalam Pasal 22E ayat 1 Undang-Undang Dasar Negara Republik Indonesia Tahun 1945. Konstitusi memang tidak memberi panduan lengkap apa yang dimaksud sesungguhnya pemilu yang adil. Oleh karenanya, perlu dilakukan penelusuran secara filosofis apa makna keadilan dalam pemilu. Diperlukan sistem pemilu alternatif yang berkeadilan sebagai jembatan antara sistem proporsional dan sistem mayoritarian (distrik) dengan mengkombinasikan kebaikan masing-masing sistem. Sistem alternatif harus mampu menciptakan partai mayoritas minimal di parlemen untuk mendukung kebijakan presiden, mampu memperbaiki akuntabilitas wakil rakyat dan mengakomodir kelompok yang heterogen. Sistem pemilu campuran dapat dipertimbangkan sebagai jembatan dua sistem antara sistem proporsional dan sistem mayoritarian (distrik) dengan mengkombinasikan kebaikan masingmasing sistem. Sistem ini dianggap mampu membenahi kelemahan utama sistem proporsional secara alamiah yaitu untuk rekayasa penciptaan sistem partai mayoritas minimal di parlemen untuk mendukung kebijakan presiden dan untuk memperbaiki akuntabilitas wakil rakyat kepada konstituennya. Disisi lain sistem campuran juga menutup kelemahan dari sistem mayoritarian yaitu the winner takes all yaitu dengan tetap menggunakan sistem proporsional untuk mengakomodir kelompok yang heterogen dan minoritas.
\end{abstract}

Kata Kunci: Pemilu; Keadilan; Presidensiil. 


\section{Pendahuluan}

Salah satu perubahan mendasar dalam sistem bertatanegara di Indonesia adalah penyaluran kedaulatan rakyat pada pemilihan umum. Pemilihan untuk memilih Presiden dan Wakil Presiden serta untuk memilih para wakil rakyat dilakukan secara langsung dalam rangkah memperkuat kedudukan atau legitimasi masingmasing yang memperoleh kedaulatan secara langsung dari rakyat. Penerapan presidensialisme di Indonesia menggunakan sistem multipartai dapat menyebabkan pemerintahan tidak berjalan dengan baik, dimana penerapan presidensialisme dengan sistem multipartai berpotensi menyebabkan partai politik melakukan intervensi pada presiden dan presiden tidak ada pilihan lain selain mengakomodasi keinginan partai politik. Penyusunan kabinet yang semula menjadi hak prerogatif presiden pada sistem presidensiil dengan multi partai presiden mengikutsertakan partai politik terlibat. Dampak adanya pengaruh partai politik dan upaya akomodasi kepentingan mengakibatkan koalisi pendukung pemerintah yang terbentuk adalah koalisi yang tidak kokoh. Kelemahan hubungan koalisi partai politik diakibatkan partai politik dengan sistem multipartai secara umum tidak mempunyai kedekatan pada aspek ideologis dan peta koalisi partai politik sering berganti. ${ }^{1}$

Upaya pemurnian sistem presidensiil yang telah dilakukan masih menyisakan perdebatan, salah satunya di seputar kekuasaan dalam membentuk undang-undang. Dalam Pasal 20 ayat 1 amandemen pertama Undang-Undang Dasar Negara Republik Indonesia (UUD NRI 1945) memberikan wewenang kekuasaan membentuk undang-undang kepada DPR, tetapi memerhatikan ayat 2 yang menentukan setiap rancangan undang-undang dibahas oleh DPR dengan Presiden untuk mendapat persetujuan bersama. Keterlibatan Presiden dalam pembentukan undang-undang untuk mendapatkan persetujuan bersama dipandang sebagai ciri mekanisme sistem parlementer. ${ }^{2}$ Ketentuan persetujuan

\footnotetext{
${ }^{1}$ Retno Saraswati, 'Desain Sistem Pemerintahan Presidensial Yang Efektif' (2012) 4 MMH Jurnal.[138].

${ }^{2}$ Saldi Isra, Pergeseran Fungsi Legislasi: Menguatnya Model Legislasi Parlementer Dalam Sistem Presidensial Indonesia (Rajawali Press 2010).[193].
} 
bersama antara Presiden dan DPR dalam membahas Rancangan undang-undang menunjukan, tidak dijalankannya separation of powers dalam sistem UUD NRI 1945. Berdasarkan pendapat tersebut dapat disimpulkan bahwa upaya purifikasi presidensiil dalam mendesain sistem pemerintahan, melalui amandemen tidak sepenuhnya dilaksanakan terutama dalam hal kekuasaan legislatif. Sebab jika konsisten dengan pemurnian sistem presidensial, maka semestinya Presiden tidak terlibat dalam pembahasan setiap rancangan undang-undang, melainkan sekedar menyetujui atau menolak terhadap setiap hasil rancangan undangundang yang ditetapkan DPR. ${ }^{3}$

Amandemen UUD NRI 1945 tampak berusaha menjawab kebutuhan pelembagaan bagi stabilitas pemerintahan dan demokrasi di tengah sistem multipartai. Pemurnian sistem presidensiil, merupakan salah satu materi utama amandemen UUD NRI 1945 yang diharapkan dapat menjaga kelangsungan stabilitas Pemerintahan dan demokrasi dengan sistem multipartai. Terbentuknya stabilitas Pemerintahan di balik sistem presidensiil dengan sistem multipartai, di dasarkan pada asumsi kemandirian eksekutif dari campur tangan legislatif melalui pemisahan kekuasaan (separation of powers). Rangkaian konsep untuk lebih menjamin kemandirian eksekutif, maka pengisian jabatan Presiden dilakukan melalui pemilihan secara langsung oleh rakyat, maka pertanggungjawaban Presiden kepada lembaga perwakilan rakyat yang dapat berakibat pemberhentian dalam masa jabatan, tidak dikenal kecuali karena alasan pelanggaran hukum sehingga masa jabatan Presiden bersifat tetap (fixed term).

Sebelum dilakukan perubahan UUD NRI 1945, ketentuan tentang pelaksanaan pemilihan umum didasarkan pada beberapa pasal dalam UUD NRI 1945. Ketentuan tersebut antara lain: Pertama, Pasal 1 ayat 2 UUD NRI 1945 yang menyebutkan "kedaulatan ada di tangan rakyat dan dilakukan sepenuhnya oleh MPR.” Sehingga sebagai bentuk pelaksanaan kedaulatan rakyat dilaksanakan pemilihan umum. Kedua, Pasal 7 UUD NRI 1945 menyebutkan, "Presiden dan

${ }^{3}$ Firdaus, Constitutional Engineering (Yrama Widya 2015).[376-378]. 
Wakil Presiden memegang jabatannya selama lima tahun dan sesudahnya dapat dipilih kembali. Dari ketentuan tersebut dapat dikembangkan bahwa pemilu di Indonesia dilaksanakan sekali dalam 5 (lima) tahun. Ketiga, Pasal 19 UUD NRI 1945 dinyatakan bahwa "susunan DPR ditetapkan dengan undang-undang". Undang-undang tersebut berkaitan dengan pelaksanaan pemilihan umum. Ketiga pasal tersebut dalam UUD NRI 1945 yang dijadikan dasar dalam pelaksanaan pemilu sebelum amandemen UUD NRI 1945.

Setelah Perubahan UUD NRI 1945 yang dilakukan MPR pada Sidang Tahunan, ketentuan pemilu secara langsung dituangkan dalam konstitusi melalui bab khusus yang mengatur tentang pemilu yaitu BAB VII B tentang Pemilihan Umum yang terdiri dari satu pasal dan enam ayat yang mengatur mengenai asasasas penyelenggaraan Pemilu, ruang lingkup penyelenggaraan Pemilu, peserta dan penyelenggara Pemilu. Sejak perubahan ketiga, Pemilu di Indonesia juga tidak lagi sebatas memilih anggota DPR tetapi juga memilih Presiden dan Wakil Presiden. Pemilihan Presiden dan Wakil Presiden yang semula dilakukan oleh MPR sebagai lembaga tertinggi negara, disepakati dilakukan secara langsung oleh rakyat sehingga pemilihan presiden dimasukkan pada rezim Pemilu.

Evaluasi secara berkala tersebut dituangkan dalam setiap peraturan perundangundangan pemilu untuk menyambut pemilu berikutnya. Hal ini pun juga perlu dilakukan karena sejatinya pemilu harus dilakukan secara berkala dalam jangka waktu yang telah ditetapkan dalam konstitusi. Perubahan pelaksanaan pemilihan umum di Indonesia salah satunya adalah dengan adanya Putusan Mahkamah Konstitusi Nomor 14/PUU-XI/2013 Tentang Pengujian Undang-Undang Nomor 42 Tahun 2008 Tentang Pemilihan Umum Presiden dan Wakil Presiden, sehingga lahir gagasan pemilu serentak, dimana kemudian pelaksanaan pemilu legislatif dan pemilu Presiden dan Wakil Presiden akan dilaksanakan secara bersamaan. Lebih lanjut, Mahkamah Konstitusi dalam putusannya menyatakan bahwa penyelenggaraan pemilu legislatif dan pemilu Presiden dan Wakil Presiden diselenggarakan secara 
serentak yang mulai berlaku pada pemilu 2019 dan pemilu seterusnya. ${ }^{4}$ Sebelumnya dalam pembahasan perubahan UUD NRI 1945 ternyata telah memperdebatkan kata "serentak" untuk masuk sebagai salah satu asas pemilu dalam dalam rancangan Pasal 22E, namun akhirnya kata serentak tersebut dihapuskan karena akan diatur lebih lanjut dalam undang-undang. ${ }^{5}$

Sistem presidensial sebagaimana disepakati oleh MPR pada proses perubahan UUD NRI 1945 akan berdampak pada tata cara pemilihan Presiden dan Wakil Presiden, bahwa dalam pelaksanaan sistem presidensial, Presiden bertanggung jawab kepada rakyat secara langsung dan tidak melalui MPR. ${ }^{6}$ Melalui momentum tersebut, Indonesia mengalami transformasi sistem dari yang sebelumnya melakukan pemilihan Presiden dan Wakil Presiden oleh MPR (indirect democracy) menjadi pemilihan Presiden dan Wakil Presiden secara langsung oleh rakyat (direct democracy).

Pemerintahan setelah amandemen UUD NRI 1945, pada beberapa segi berusaha melalukan purifikasi presidensial melalui pemilihan Presiden dan Wakil Presiden secara langsung, serta masa jabatan yang bersifat tetap, kecuali jika terjadi pemakzulan akibat pelanggaran hukum sebagaimana diatur dalam Pasal 7A UUD 1945. Hal tersebut berimplikasi terhadap tingkat kemandirian Presiden berhadapan dengan DPR. Berdasarkan hal tersebut, secara konstitusional stabilitas Pemerintahan dari sudut pandang stabilitas masa jabatan jauh lebih stabil, dibanding sebelum amandemen UUD NRI 1945, tanpa terpengaruh oleh jenis sistem kepartaian apa pun. Namun, stabilitas Pemerintah menjadi berbeda jika dilihat dari sudut pandang stabilitas kebijakan, sebab bagaimanapun DPR setelah

${ }^{4}$ Lihat Putusan Mahkamah Konstitusi No. 14/PUU-XI/2013 dalam perkara pengujian Undang-Undang No. 42 Tahun 2008 Tentang Pemilihan Umum Presiden dan Wakil Presiden terhadap UUD Negara RI Tahun 1945.

${ }^{5}$ Mahkamah Konstitusi, Naskah Komprehensif Perubahan Undang-Undang Dasar Negara Republik Indonesia Tahun 1945, Latar Belakang, Proses, Dan Hasil Pembahasan, 1999-2002, Buku V Pemilihan Umum (Edisi Revi, Sekretariat Jenderal dan Kepaniteraan Mahkamah Konstitusi 2010).[517-521].

${ }^{6}$ Jimly Asshiddiqie, Konstitusi Dan Konstitusionalisme Indonesia (Sinar Grafika 2010).[62-63] dan [168-169]. 
amandemen UUD NRI 1945 Pasal 20A ayat 1 memiliki fungsi legislasi, fungsi anggaran, dan fungsi pengawasan yang dapat berdampak terhadap penyelenggaraan kekuasaan eksekutif oleh Presiden. Berdasarkan fungsi-fungsi tersebut dalam ayat 2, DPR mempunyai hak interpelasi, hak angket, dan hak menyatakan pendapat, sehingga jalannya pemerintahan berjalan di atas berbagai peraturan perundangundangan dimana undang-undang sendiri lahir atas persetujuan bersama DPR dan Presiden (Pasal 20 ayat 2 UUD NRI 1945). Rangkaian konstruksi pola hubungan kewenangan antara DPR dan Presiden setelah amandemen UUD NRI 1945, menunjukkan bahwa stabilitas pemerintahan, terutama stabilitas kebijakan ditentukan keharmonisan hubungan antara DPR dan Presiden, yang terbangun dari adanya persesuaian kehendak antara keduanya. ${ }^{7}$

Untuk mendukung penguatan sistem presidensiil maka dibentuklah UndangUndang Nomor 7 Tahun 2017 Tentang Pemilihan Umum (UU No.7/2017) yang menjadi langkah awal kodifikasi perundang-undangan tentang pemilihan umum dan mengakomodir pengaturan pemilu serentak untuk tahun 2019. Pertanyaan berikutnya, apakah keberadaan UU No.7/2017 tersebut telah mencerminkan prinsip keadilan dan mampu memperkuat sistem presidensiil di Indonesia. Berdasarkan latar belakang tersebut maka penulis akan menganalisis masalah tentang "Penataan sistem pemilihan umum yang berkeadilan untuk penguatan sistem presidensiil di Indonesia”.

\section{Konsep Keadilan Dalam Pemilu}

Dalam Pasal 22E ayat 1 UUD NRI 1945 dinyatakan, pemilihan umum dilaksanakan secara langsung, umum, bebas, rahasia, jujur dan adil setiap lima tahun sekali. Sesuai ketentuan tersebut, "adil” merupakan salah satu asas penyelenggaraan pemilu. Oleh karena itu, asas tersebut haruslah menjiwai sistem pemilu yang terdiri dari hukum pemilu (electoral law) maupun proses penyelenggaraan pemilu (electoral process).

${ }^{7}$ ibid.[389-391]. 
Diadopsinya asas “adil” dalam norma konstitusi terkait pemilu menunjukkan bahwa perwujudan negara hukum yang demokratis sebagaimana diamanatkan dalam Pasal 1 UUD NRI 1945 haruslah dilakukan secara berkeadilan. Peralihan sekaligus pelaksaaan kedaulatan tertinggi negara yang berada di tangan rakyat tidak boleh dilakukan secara tidak fair. Dalam arti, kehendak atau suara rakyat dalam pemilu jangan sampai dikhianati dengan cara-cara membelokkannya menjadi kehendak elit secara curang dan keadilan merupakan prinsip sekaligus mandat yang mesti diwujudkan dalam penyelenggaraan setiap pemilihan umum. ${ }^{8}$

Apa yang dimaksud dengan keadilan pemilu? Terkait hal tersebut, IDEA mencatat bahwa electoral justice adalah dalam kerangka itu, keadilan pemilu mencakup sarana dan mekanisme serta mengandung tiga elemen, yaitu pencegahan terhadap sengketa pemilu (prevention of electoral disputes), penyelesaian terhadap sengketa pemilu (resolution of electoral disputes), dan alternatif penyelesaian sengketa pemilu di luar mekanisme yang ada (alternative of electoral disputes). Penyelesaian terhadap sengketa pemilu dapat dibagi ke dalam dua hal, yaitu koreksi terhadap kecurangan melalui electoral challenges dan hukuman bagi mereka yang melakukan kecurangan baik secara administatif maupun pidana. ${ }^{9}$

Dengan demikian, ukuran adil atau tidaknya pemilu menurut standar yang dirumuskan IDEA bergantung pada ada atau tidaknya ketersediaan instrumen hukum pemilu beserta mekanisme penyelesaian masalah hukum pemilu yang terjadi. Sekalipun definisi keadilan pemilu yang dikemukan IDEA berangkat dari paradigma adanya jaminan terhadap hak pilih warga negara. ${ }^{10}$ Kemudian menurut Ramlan Surbakti mengemukakan tujuh kriteria yang harus dipenuhi untuk mewujudkan pemilu yang adil dan berintegritas. Tujuh kriteria tersebut adalah: 1) kesetaraan antarwarga negara, baik dalam pemungutan dan penghitungan suara maupun dalam alokasi kursi DPR dan DPRD dan pembentukan daerah pemilihan;

${ }^{8}$ Khairul Fahmi, 'Menelusuri Konsep Keadilan Pemilihan Umum Menurut UUD 1945’ (2016) 4 Jurnal Cita Hukum.[168].

${ }_{9}^{9}$ Ayman Ayoub dan Andrew Ellis (ed), Electoral Justice: The International IDEA Handbook (International IDEA).[10].

${ }^{10}$ Veri Junaidi,[et.,al.], Evaluasi Penegakan Hukum Pemilu 2014 (Perludem 2015).[4]. 
2) kepastian hukum yang dirumuskan berdasarkan asas pemilu demokratis; 3) persaingan bebas dan adil antarkontestan pemilu; 4) partisipasi seluruh pemangku kepentingan dalam seluruh rangkaian penyelenggaraan tahap pemilu; 5) badan penyelenggara pemilu yang profesional, independen, dan imparsial; 6) integritas pemungutan, penghitungan, tabulasi, dan pelaporan suara pemilu; 7) penyelesaian sengketa pemilu yang adil dan tepat waktu. ${ }^{11}$

Tujuh kriteria yang dikemukakan Ramlan di atas tidak hanya mengukur pemilu dari aspek regulasi dan tersedianya mekanisme komplain, melainkan juga menyentuh aspek kesetaraan antarwarga negara dan persaingan yang bebas dan adil. Kesetaraan antarwarga negara dijelaskan sebagai kesetaraan baik dalam pencalonan, pemungutan, penghitungan suara maupun alokasi kursi DPR dan DPRD. Sementara persaingan yang bebas dan adil diartikan sebagai suatu kontestasi di mana para kontestan berangkat dan bersaing dari titik tolak yang sama dan setara. Terkait hal itu, pendapat Ramlan tentu dapat diamini, hal tersebut merupakan salah satu aspek penting keadilan pemilu adalah terwujudnya kesetaraan antar warga negara dan terlaksananya kontestasi yang bebas dan adil. Lalu, apa sesungguhnya definisi keadilan pemilu?.

Dalam pandangan Rawls berdasarkan prinsip "Justice as Fairness" terdapat dua prinsip keadilan yang penting yaitu: Liberty Principle dan Difference Principle. Dalam konteks Liberty Principle dalam pandangan Rawls dinyatakan bahwa: each person is to have an equal rights to the most extensive basic liberty compatible with a similar liberty for others. ${ }^{12}$ Hak-hak kebebasan dasar yang sama bagi semua warga negara meliputi kebebasan politik untuk memilih dan dipilih untuk jabatan-jabatan publik, kebebasan berpendapat dan berkumpul, kebebasan berkeyakinan, kebebasan untuk mempunyai milik pribadi dan kebebasan dari penahanan secara sewenangwenang. Keadilan merupakan sesuatu gagasan yang berlaku umum tetapi pada akhirnya dapat dirasakan secara subyektif. Sebagaimana Rawls berpendapat:”... in

${ }^{11}$ Ramlan Surbakti, 'Pemilu Berintegritas Dan Adil' Harian Kompas edisi 14 (February 2014).[6].

${ }^{12}$ John Rawls, $A$ Theory of Justice (Harvard University Press 1999).[220-226]. 
a well-ordered society, one effectively regulated by a shared conception of justice, there is also a public understanding as to what is just and unjust. ${ }^{13}$

Teori keadilan sebagai fairness sebagaimana dikemukakan Rawls hanya bisa diterapkan dalam suatu masyarakat demokratis, di mana di dalam masyarakat tersebut mereka tunduk pada peraturan-peraturan dan hukum-hukum yang dibuat, diterima, dan diakui keberlakuannya oleh masyarakat itu sendiri. Artinya, keadilan hanya bisa diwujudkan dalam suatu tatanan masyarakat, bukan secara individu. Dalam konteks itu, apa yang dikemukakan Rawls sejalan dengan apa yang juga pernah dikemukakan Hans Kelsen. Bagi Kelsen, keadilan adalah kebahagiaan yang tidak bisa ditemukan sebagai seorang individu, sehingga ia harus dicari dalam masyarakat. Sehingga keadilan itu dapat dikatakan sebagai suatu kebahagian sosial. Selengkapnya Kelsen mengemukan: The longing for justice, considered psychologically, is the eternal longing of man for happiness, which he cannot find as an individual and threrefore seeks in society. Social happiness is called "justice". ${ }^{14}$

Pada suatu tatanan masyarakat, khususnya masyarakat demokratis diasumsikan bahwa setiap individu memiliki kebebasan dan tanggung jawab atas dirinya sendiri dalam pergaulan yang demokratis. Dalam pergaulan tersebut, kebebasan individu hanya boleh dibatasi oleh kebebasan yang lainnya. Rawls mengatakan, dalam perspektif keadilan sebagai fairness, kebebasan dapat dibatasi karena alasan bahwa pembatasan tersebut dapat mengakibatkan ketidaksamaan dalam kebebasan politik, akan tetapi ketidaksamaan tersebut diperbolehkan apabila hal itu penting demi terjaminnya kebebasan dari kelompok yang kurang beruntung.

Terlepas dari berbagai kritik yang dihadapkan pada teori keadilan yang dikemukakan Rawls, setidaknya apa yang ia kemukan dapat digunakan untuk menilai apakah pengaturan hak tertentu dapat dikatakan adil atau tidak, termasuk dalam menilai pengaturan hak memilih dan dipilih. Sekalipun hak tersebut merupakan hak dasar, namun pendistribusiannya sama sekali tidak

${ }^{13}$ ibid. [49].

${ }^{14}$ Hans Kelsen, Introduction to The Problems of Legal Theory (Bonnie Litschewski Paulson and Stanley L. Paulson ed, Clarendon Press 1992).[16]. 
dapat dilepas atau harus sejalan dengan prinsip distribusi kekayaan pendapatan dan hierarkhi otoritas. Dengan demikian, pembatasan-pembatasan tertentu terhadap hak memilih dan dipilih untuk tujuan memberikan keuntungan bagi semua orang adalah dibenarkan.

Kembali ke pertanyaan awal tentang apa itu keadilan pemilu, maka prinsipprinsip keadilan sebagaimana dielaborasi di atas, terutama teori keadilan sebagai fairness sebagaimana dikemukakan John Ralws dan konsep keadilan sosial sebagaimana dikandung filosofi negara Indonesia merupakan prinsip yang secara inheren harus ada dalam penyelenggaraan pemilu. Dalam arti, bahwa keadilan pemilu akan berwujud dalam suatu aturan atau kebijakan yang diterapkan menurut prinsip-prinsip keadilan sebagai fairness yang juga bersesuaian dengan prinsip keadilan sosial yang terkandung dalam sila kelima Pancasila. Sesuai hal itu, keadilan pemilu dapat dirumuskan sebagai pelaksanaan pemilu yang tunduk pada aturanaturan (termasuk pembatasan-pembatasan) hukum pemilu yang adil dan memberi ruang kebebasan dan kesetaraan antar warga negara dalam suatu sistem demokrasi yang menguntungkan semua warga negara. ${ }^{15}$

Dalam konteks ini, keadilan pemilu tidak hanya terhenti pada bagaimana menciptakan sebuah aturan main yang adil dan berkepastian hukum, melainkan juga dapat dijadikan sebagai alat untuk menjaga suara rakyat. Keadilan pemilu tidak hanya terhenti pada tersedianya mekanisme penyelesaian sengketa dalam berbagai bentuknya, melainkan juga mampu memastikan bahwa semua warga negara terjamin hak-haknya dari kemungkinan berbagai kecurangan yang terjadi.

Keadilan akan terus mengalami perdebatan panjang sebagaimana pandangan Amartya Sen: Justice is an immensely important idea that has moved people in the past and will continue to move people in the future, ${ }^{16}$ begitu juga keadilan dalam sistem pemilu akan terus mengalami dinamika. Menjadi penting bagaimana keadilan pemilu tercermin sampai pada level bagaimana institusi penyelenggara pemilu diisi oleh orang-orang non partisan serta mampu bekerja dengan integritas

\footnotetext{
${ }^{15}$ Khairul Fahmi.Op.Cit.[184].

${ }^{16}$ Amartya Sen, The Idea of Justice (Harvard University Press 2009).[401].
} 
yang terjaga. Bahkan, keadilan pemilu juga menjangkau titik yang paling rumit, di mana rakyat sebagai tumpuan demokrasi memiliki pemahaman yang cukup akan keberadaannya sebagai penentu proses peralihan kekuasaan melalui pemilu yang berjalan secara fair. Dengan demikian, keadilan pemilu mencakup semua aspek yang mempengaruhi bagaimana pemilu sebagai sebuah kontestasi berjalan secara bebas dan setara. ${ }^{17}$

\section{Sistem Pemilu Menurut UUD NRI 1945}

Salah satu perubahan mendasar dalam ketentuan mengenai pemilihan umum yaitu dimasukannya Pemilihan Presiden ke dalam Rezim Pemilu dikarenakan adanya perubahan dalam UUD NRI 1945 atas perspektif kedaulatan rakyat. Perdebatan pandangan tersebut mengakibatkan diubahnya bunyi pada Pasal 1 ayat 2 UUD 1945. Awalnya, Pasal 1 ayat 2 UUD NRI 1945 menyebutkan "kedaulatan adalah ditangan rakyat, dan dilakukan sepenuhnya oleh Majelis Permusyawaratan Rakyat”. Kemudian diubah pada saat amandemen ketiga UUD NRI 1945 sehingga pasal tersebut berubah menjadi: "kedaulatan berada di tangan rakyat dan dilaksanakan menurut Undang-Undang Dasar”. MPR semula menjadi pemegang kedaulatan sepenuhnya dari rakyat atau pemegang mandat rakyat tertinggi, berubah pada pandangan bahwa MPR tidak lagi sebagai penerima mandat tunggal tertinggi, melainkan mandat kedaulatan tersebut dilaksanakan menurut UUD NRI 1945. ${ }^{18}$ Oleh karena itu, mandat kedaulatan rakyat dilaksanakan oleh cabang-cabang kekuasaan negara menurut Undang Undang Dasar, termasuk juga dilaksanakan MPR sebagai salah satu lembaga yang menyelenggarakan kekuasaan negara. Alasan dilakukan perubahan pada rumusan Pasal 1 ayat 2 karena dipandang berisi ketentuan yang tidak jelas yaitu dengan adanya kalimat “...dilakukan sepenuhnya oleh Majelis Permusyawaratan Rakyat” maka hal tersebut dapat diartikan hanya MPR yang melaksanakan kedaulatan

\footnotetext{
${ }^{17}$ Khairul Fahmi.Op.Cit.[184].

${ }^{18}$ Soewoto Mulyosudarmo, Pembaharuan Ketatanegaraan Melalui Perubahan Konstitusi (Asosiasi Pengajar HTN dan HAN dan In-TRANS 2004).[3].
} 
rakyat dan DPR yang semestinya merupakan perwujudan wakil rakyat dianggap bukan sebagai pelaksana kedaulatan rakyat.

Perubahan pada Pasal 1 ayat 2 UUD 1945 mencerminkan adanya perubahan konsep yang sangat mendasar tentang pelaksanaan kedaulatan rakyat dalam UUD 1945. Terjadi perubahan penting tentang siapa yang sesungguhnya bertindak sebagai pemegang kekuasaan tertinggi kedaulatan rakyat. Soewoto Mulyosudarmo berpendapat bahwa perubahan Pasal 1 ayat 2 UUD NRI 1945 adalah perubahan menjadi pada keadaan yang sesungguhnya mengenai pengaturan kekuasaan tertinggi yaitu rakyat sebagai pemilik kekuasaan tertinggi dalam negara dan pelaksanaannya dilakukan sesuai dengan UUD NRI 1945. ${ }^{19}$

Ciri utama dari konsep kedaulatan rakyat dalam sistem demokrasi yaitu rakyat dijamin terlibat penuh dalam pelaksanaan fungsi kekuasaan mulai dari tahap perencanaan, pengaturan, pelaksanaan dan pelaksanaan. Peran serta rakyat dalam pelaksanaan pemerintahan tersebut haruslah dilaksanakan menurut Undang-Undang Dasar, tidak lagi dilakukan melalui lembaga Majelis Permusyawaratan Rakyat seperti ketentuan sebelum perubahan UUD NRI 1945. Perbedaan cukup penting setelah perubahan UUD 1945 yaitu: pertama, kedaulatan ada di tangan rakyat dan tidak lagi dilembagakan hanya pada satu lembaga MPR sebagai penjelmaan tunggal lembaga negara. Pada rumusan yang baru, semua lembaga negara dipahami sebagai perwujudan adanya pelaksanaan kedaulatan rakyat. Kedua, semua lembaga negara tidak hanya MPR saja yang diharuskan melaksanakan tugas menurut ketentuan Undang-Undang Dasar, melainkan semua lembaga negara harus menjalankan tugasnya berdasarkan ketentuan Undang-Undang Dasar.

Menurut Moh. Kusnardi dan Harmailly Ibrahim pada negara dengan konsep kedaulatan rakyat atau dikenal dengan negara demokrasi, rakyatlah yang dipandang sebagai pemegang atau pemilik tunggal kekuasaan tertinggi pada suatu negara. ${ }^{20}$ Rakyatlah sebagai penentu seperti apa pemerintahan diselenggarakan. Rakyat juga

${ }^{19}$ ibid.

${ }^{20}$ Moh. Kusnardi dan Harmailly Ibrahim, Pengantar Hukum Tata Negara Indonesia (FHUI 1980).[328]. 
sebagai penentu tujuan negara dan pemerintahan yang ingin dicapai. Untuk suatu negara kecil dengan jumlah penduduknya sedikit, dan juga memiliki luas wilayah yang tidak besar, kedaulatan rakyat pada negara ini dapat dilaksanakan secara langsung.

Pada negara yang memiliki jumlah penduduk besar dan juga memiliki luas wilayah yang besar, sangat sulit untuk dapat menghimpun pendapat rakyat secara langsung pada masing-masing individu untuk menentukan jalannya pemerintahan. Selain itu pada kondisi masyarakat modern dengan latar belakang kondisi masyarakat yang berkembang sangat cepat dengan masalah yang sangat beragam, rakyat memiliki jenis pekerjaan, keahlian yang berbeda, kecerdasan antar individu dalam masyarakat yang berbeda. Kondisi demikian menjadi faktor penyebab kedaulatan rakyat tidak dapat diterapkan secara murni dengan cara langsung seperti penerapan pada masa terdahulu. Prinsip kedaulatan rakyat harus tetap ditegakkan dengan melihat kondisi dan kebutuhan masyarakat sehingga hal ini yang menjadi dasar pembenaran untuk dilaksanakan kedaulatan rakyat melalui sistem perwakilan (representation).

Wakil rakyat yang dipih sebagai bentuk pelaksanaan sistem perwakilan harus dipilih secara langsung oleh rakyat melalui suatu mekanisme yang dikenal dengan nama pemilihan umum (general election) sebagai bentuk pelaksanaan atas kehendak seluruh rakyat. Jadi pemilihan umum adalah sebagai proses dalam menentukan para wakil rakyat secara demokratis. Suatu negara yang menyatakan dirinya merupakan negara demokratis maka pelaksanaan pemilihan umum merupakan ciri penting dan harus diwujudkan dalam waktu-waktu yang tertentu yang telah ditetapkan.

Pada negara demokrasi setiap warga negara harus diberikan kesempatan untuk memberikan pandangannya tentang apa yang harus dilakukan oleh pemerintah, warga negara diberikan hak untuk memilih para pembuat aturan dan memilih kandidat yang akan berlaga pada pemilihan umum. Partisipasi atau keterlibatan merupakan hal yang sangat penting dan menantang pada negara demokrasi. Hal tersebut sejalan dengan apa yang ditulis oleh André Blais yang menjelaskan bahwa:

"In a democracy, every citizen should have the right to express his or her views about what the government should do, should have the right to vote and to have a say about the selection of lawmakers, and should have the right to run as a candidate in elections if he or she so wishes. A democracy is a polity 
in which citizens are given the opportunity to participate. Many democratic theorists argue that without substantial citizen participation democracy falls short of its goals and that as a consequence the quality of democracy in a given polity can be ascertained by the degree of citizen involvement. Participation is a "good" thing, and a crucial challenge is to understand why so many people remain "passive" citizens". ${ }^{21}$

Perubahan konsep kedaulatan rakyat sebagaimana diatur dalam UUD NRI 1945 secara langsung juga mempengaruhi pada cara bagaimana rakyat memberikan mandat pada penyelenggara kekuasaan negara. Sebagai contoh yang bisa dilihat pada pemilihan Presiden. Presiden yang semula dipilih oleh MPR sekarang Presiden dipilih langsung oleh rakyat. Begitu juga cara pemberian mandat yang diberikan pada para wakil rakyat, dimana seluruh anggota DPR dan DPD dipilih melalui mekanisme pemilihan umum dan tidak ada anggota wakil rakyat yang dipilih melalui mekanisme penunjukan seperti pernah terjadi sebelumnya.

Untuk penyelenggaraan Pemilihan Umum diatur dalam Pasal 22E ayat 1 UUD NRI 1945 yang menyatakan bahwa pemilihan umum dilaksanakan secara langsung, umum, bebas, rahasia, jujur dan adil setiap lima tahun sekali. Sesuai ketentuan tersebut, maka lima asas dalam pemilu tersebut yaitu: langsung, umum, bebas, rahasia, jujur dan adil haruslah menjiwai sistem pemilu yang terdiri dari hukum pemilu (electoral law) maupun proses penyelenggaraan pemilu (electoral process).

Kemudian sebagai perbandingan dapat dilihat pada Universal Declaration on Democracy yang diadopsi oleh Inter-Parliamentary Union, Pemilu merupakan elemen kunci untuk menjalankan demokrasi. Bagian Kedua angka 12 deklarasi ini menyatakan: ${ }^{22}$

"The key element in the exercise of democracy is the holding of free and fair elections at regular intervals enabling the people's will to be expressed. These election must be held on the basis of universal, equal and secret suffrage so that all voters can choose their representatives in conditions of equality,

${ }^{21}$ Lawrence LeDuc,[et.,al.], Comparing Democracy 3: Elections and Voting in the 21st (Century SAGE Publications 2010).[165].

${ }^{22}$ Para 12, Second Part - The Elements and Exercise of Democratic Government, Universal Declaration on Democracy. Adopted without a vote by the Inter-Parliamentary Council at its 161st session, Cairo, 16 September 1997. 
openness and transparency that stimulate political competition. To the end, civil and political rights are essential, and more particulary among them, the rights to vote and to be elected, the rights to freedom of expression and assembly, access to information and the right to organise political parties and carry out political activities. Party organisation, activities, finances, funding and ethics must be properly regulated in an impartial manner in order to ensure the integrity of the democratic processes".

Berdasarkan deklarasi tersebut, pemilu yang diselenggarakan untuk menjalankan demokrasi harus memenuhi beberapa prinsip yaitu bebas (free), adil (fair), berkala (regular), umum (universal), persamaan (equal), dan rahasia (secret). Selain itu juga harus terdapat penghormatan terhadap hak memilih dan dipilih (rights to vote and to be elected), kebebasan berekspresi dan berkumpul (rights to freedom of expression and assembly), akses terhadap informasi (access to information), dan kebebasan berorganisasi (freedom of organization).

\section{Sistem Pemilu Untuk Penguatan Sistem Presidensiil di Indonesia}

Secara umum sistem pemerintahan yang dikenal dunia dan menunjukan pola hubungan sistem pemerintahan demokrasi, yakni sistem pemerintahan parlementer (parliamentary system) dan sistem pemerintahan presidensial (presidential system). Sebagaimana pandangan Joses Antonio yang menjelaskan bahwa: "the are two basic forms of democratic goverments. In one the government depends on the confidence of the legislature in order to exist. In the other the government, or more precisely its head, serves for a fixed term; thus the executive and the legislature are independent from one another". ${ }^{23}$ Dalam praktik terdapat sistem pemerintahan yang mengombinasi unsur-unsur dari kedua sistem tersebut yang dikenal dengan sistem pemerintahan kombinasi atau campuran (mixed system atau hybrid system). ${ }^{24}$

Pada sistem presidensial menunjukkan pola hubungan yang berbeda dengan sistem parlementer. Sistem presidensial cenderung pada eksekutif yang mandiri

${ }^{23}$ Joses Antonio Cheibub, Presidentialism, Parliamentarism and Democracy (Cambridge University Press 2007).[1].

${ }^{24}$ Jimly Asshiddiqie, Pokok-Pokok Hukum Tata Negara Indonesia Pasca Reformasi (Bhuana Ilmu Populer 2007).[311]. 
(non parliamentary executive) melalui gagasan pemisahan dan pembagian kekuasaan. Gagasan pemisahan kekuasaan berorientasi ada kemandirian dan kebebasan, sedangkan pembagian kekuasaan berakar pada keseimbangan dan kontrol antara cabang kekuasaan. ${ }^{25}$ Sesuai dengan gagasan tersebut, eksekutif dipilih oleh rakyat secara langsung dengan memegang dua kualitas, baik sebagai kepala negara (nominal executive) maupun sebagai kepala pemerintah (real executive). ${ }^{26}$ Umumnya sistem presidensial dianut oleh negara-negara republik yang eksekutifnya dipimpin oleh presiden. Oleh karena itu, eksekutif memiliki masa jabatan yang bersifat tetap (fixed term atau fixed executive) dan bertanggung jawab kepada rakyat. Pemberhentian dalam masa jabatan dapat dilakukan jika presiden terbukti melakukan pelanggaran hukum.

Aspek penting atas seluruh usaha penataan sistem pemerintahan dimaksudkan untuk memaksimalkan performa pemerintahan yang berorientasi pada perwujudan kedaulatan dan kesejahteraan rakyat. Sebagai bagian penting dari proses konsolidasi demokrasi di tingkat suprastruktur politik, sistem pemerintahan memberi bentuk dan pola pengelolaan konflik secara tertib dan terlembaga antar kekuatan politik sehingga berefek pada sikap dan keputusan aktor politik dalam penyelenggaraan pemerintahan. Oleh karena itu, sistem pemerintahan selain berperan dalam ikhtiar membangun stabilitas pemerintahan, juga berperan penting dalam menjaga stabilitas demokrasi yang menjamin partisipasi rakyat secara bebas dan setara untuk memilih dan dipilih dalam jabatan-jabatan pemerintahan. Partisipasi bermakna penyaluran segala bentuk aspirasi nilai dan kepentingan rakyat secara tertib, untuk mempengaruhi proses pengambilan keputusan-keputusan otoritas dalam penyelenggaraan pemerintahan negara. ${ }^{27}$

PandanganScott Mainwaring menjelaskan bahwakombinasi sistem multipartai dan sistem presidensiil adalah sesuatu yang sulit dan menciptakan ketidakstabilan

${ }^{25}$ Daniel E. Branner Jr., Checks and Balances: The Three Branches of the American Government, Volume 1 (Thomson Gale 2005).[1]. dalam Firdaus.Op.Cit.[28].

${ }^{26}$ Jimly Asshiddiqie, Format Kelembagaan Negara Dan Pergeseran Kekuasaan Dalam UUD 1945 (FH UII Press 2004).[59-60].

${ }^{27}$ Miriam Budiarjo, Dasar-Dasar Ilmu Politik (Gramedia Pustaka Utama 2008).[367-368]. 
dalam pemerintahan. Mainwaring menjelaskan tiga alasan permasalahan kombinasi antara sistem multipartai dan sistem presidensiil: ${ }^{28}$

"first, multiparty presidentialism is specially likely to produce immobilism executive/legislative and such deadlock can destabilize democracy; second, multipartism is more likely than bipartism to produce ideological polarization, thereby complicating problem often associated with presidentialism; and finally, the combination multipartism and presidentialism is complicated by the difficulties of interparty coalition building in presidential democracy, with deleterious of consequences for democratic stability".

Pandangan Mainwaring tersebut menjelaskan bahwa presidensialisme multipartai kemungkinan menyebabkan kebuntuhan antara eksekutif dan legislatif dan sulitnya membangun koalisi antarpartai dalam demokrasi presidensial, sehingga berkonsekuensi merusak terhadap stabilitas demokrasi.

Sementara Juan Linz dari sudut pandang yang berbeda menjelaskan bahwa desain kelembagaan yang terpisah antara kekuasaan legislatif dan kekuasaan eksekutif, menyebabkan antara satu dengan yang lainnya memiliki kemandirian bertindak yang bisa saja bertentangan antara satu dengan yang lainnya. Pemilihan presiden secara langsung oleh rakyat, serta masa jabatan yang bersifat tetap menjadi dasar klaim legitimasi presiden yang berhadapan dengan lembaga legislatif. Adanya dual legitimasi dengan masingmasing, memiliki kekuasaan yang mandiri serta tidak dapat saling mengintervensi antara satu dengan yang lainnya, merupakan potensi besar terjadinya kebuntuan dalam sistem pemerintahan presidensiil. Sebagaimana pendapat dari Juan Linz yang menyatakan:

"But what is most striking is that in a presidential system, the legislators, especially when they represent cohesive, disciplined parties that offer clear ideological and political alternatives, can also claim democratic legitimacy. This claim is thrown into high relief when a majority of the legislature represents a political option opposed to the one the president represents. Under such circumstances, who has the stronger claim to speak on behalf of the people: the president or the legislative majority that opposes his policies? Since both derive their power from the votes of the people in a free competition among well-defined alternatives, a conflict is always possible and at times may erupt dramatically. "29

${ }^{28}$ Scott Mainwaring, Presidentialism, Multipartism and Democracy: The Difficult Combination, Comparative Political Studies Vol 26 No. 2 (Sage Publications 1993).[198-225].

${ }^{29}$ Juan J. Linz, 'The Perils of Presidentialism' (1990) 1 Journal of Democracy.[53]. 
Hal demikian diakui pula oleh José Antonio Cheibub bahwa kebuntuan sistem presidensiil disebabkan oleh kemungkinan presiden terpilih serta anggota legislatif yang menguasai mayoritas kursi di lembaga perwakilan rakyat berasal dari partai yang berbeda. Dalam situasi demikian, sistem presidensiil tidak memiliki prinsipprinsip demokrasi yang dapat memecahkan atau mekanisme konstitusional, untuk menyelesaikan kebuntuan seperti membubarkan anggota parlemen dan segera menyelenggarakan pemilu untuk membentuk pemerintahan baru. ${ }^{30}$

Dalam kerangka stabilitas pemerintahan dan kelangsungan demokrasi, amandemen UUD NRI 1945 didasarkan pada konsep pemisahan dan pembagian kekuasaan(separation and distribution of powers) serta penegasan sistem pemerintahan presidensiil dengan harapan tercipta kemandirian dan kesetaraan, serta keseimbangan dan kontrol (check and balances) antara cabang kekuasaan. ${ }^{31}$ Penelitian Mark P. Jones, sebagaimana dikutip oleh Djayadi Hanan dilihat dapat mewakili konsep umum dalam penguatan sistem presidensial. Pada salah satu publikasi penelitiannya pada tahun 1995, Jones menerangkan bahwa: “...all evidence indicates the functioning of presidential systems is greatly enhanced when the president is provided with a majority or near majority in the legislature". ${ }^{32}$

Pada pandangan Jones tersebut diatas menjelaskan bahwa untuk dapat memperkuat sistem presidensial berhubungan erat dengan adanya dukungan politik yang cukup pada lembaga legislatif bagi seorang presiden. Dukungan tersebut diterapkan secara teknis dengan bentuk suara 50 persen di parlemen atau sedikitnya mendekati 50 persen. Seorang presiden berpotensi mendapatkan kesulitan dalam menjalankan program pemerintahan apabila presiden hanya mendapatkan dukungan kurang dari batas minimal tersebut.

Secara umum sistem pemilu yang dikenal ada dua yaitu konsep perwakilan proporsional (proportional representation) dan konsep perwakilan distrik (district

\footnotetext{
${ }^{30}$ José Antonio Cheibub, Minority Presidents, Deadlock Situations, and the Survival of Presidential Democracies (Yale University Press).[277-283].

31 Jimly Asshiddiqie, Format Kelembagaan Negara Dan Pergeseran Kekuasaan Dalam UUD 1945 (FH UII Press 2005).[11].

${ }^{32}$ Djayadi Hanan, 'Memperkuat Presidensialisme Multipartai Di Indonesia: Pemilu Serentak, Sistem Pemilu Dan Sistem Kepartaian’ (2017) < http://puskapol.ui.ac.id> accessed 7 November 2018.
} 
representation), tetapi tidak menutup kemungkinan terjadinya kombinasi di antara keduanya. Konsep perwakilan proporsional mendesain perwakilan secara berimbang antara jumlah wakil dengan jumlah perolehan suara secara nasional, sedangkan konsep perwakilan distrik membagi wakil berdasarkan distrik pemilihan. Perpaduan antara konsep perwakilan distrik dan proporsional ditujukan untuk mengombinasi guna saling melengkapi kekurangan di antara keduanya.

Bagan 1. Kerangka Penguatan Sistem Presidensiil Melalui Sistem Pemilu

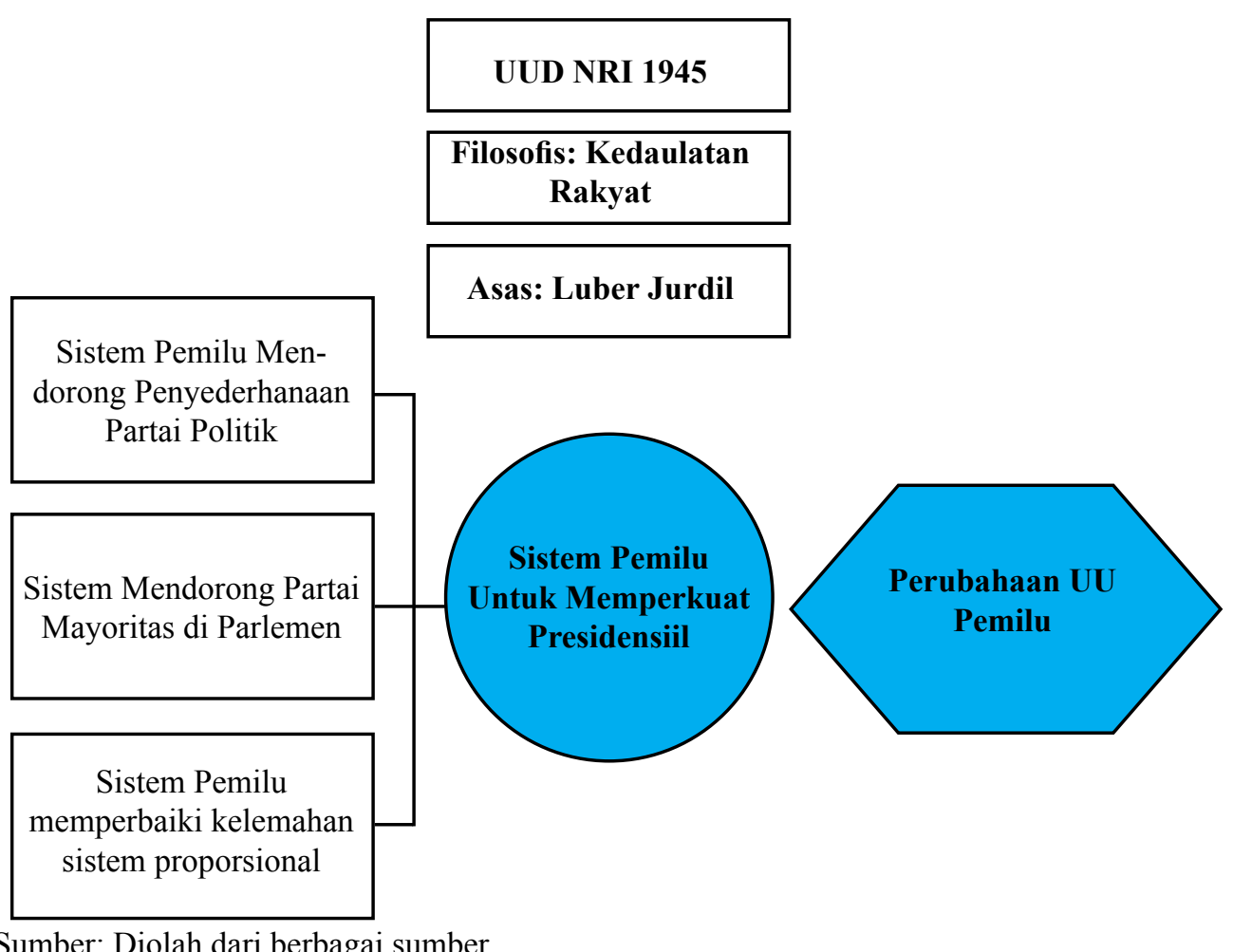

Sumber: Diolah dari berbagai sumber.

Pada sistem pemilu proporsional, dimana distribusi kursi di antara partai politik peserta pemilu dibagi berdasarkan proporsi perolehan suara secara nasional menurut jumlah bilangan pembagi tertentu. Proporsi perolehan suara partai secara nasional, sebagai dasar pembagian kursi dalam lembaga perwakilan rakyat, memperkecil terbuangnya sisa suara serta memperbesar peluang keterwakilan rakyat, hingga pada partai-partai politik terkecil. Sistem pemilu proporsional cenderung memperbesar jumlah partai efektif yang berdampak pada terbentuknya sistem multipartai. Polarisasi yang tercipta dalam sistem multipartai tidak jarang memicu instabilitas pemerintahan dan demokrasi, yang disebabkan oleh sulitnya menyatukan berbagai 
kutub kepentingan yang saling bertabrakan. Untuk mengendalikan hal itu, pada beberapa negara yang menerapkan sistem pemilu proporsional, mereka menerapkan kriteria tertentu untuk mengendalikan jumlah partai efektif. Di antara kriteria tersebut adalah penerapan electoral threshold (ambang batas minimum perolehan suara dalam pemilu) dan parliamentary threshold (ambang batas minimum wakil partai dalam lembaga perwakilan), sebagai salah satu syarat kepesertaan partai untuk ikut pemilu. Di samping itu, langkah pengendalian kepesertaan partai dalam pemilu juga dilakukan dengan menetapkan minimum persebaran pengurus baik pada level provinsi maupun pada level kabupaten/kota. ${ }^{33}$

Sistem distrik adalah salah satu sistem pemilu yang dalam banyak segi cenderung mengendalikan jumlah partai efektif. Hal tersebut terjadi karena suatu negara dibagi dalam beberapa distrik yang mana pembagian kursi, didasarkan pada satu distrik, dimana satu orang wakil dengan mekanisme suara terbanyak (plurality system) atau first past the post. Artinya, pemenang suara terbanyak pertama mewakili distriknya, sedangkan calon pemenang kedua, ketiga, dan seterusnya terbuang begitu saja tanpa dapat diperhitungkan dan dijadikan bilangan pembagi dalam perolehan kursi. Akibatnya, sistem pemilu distrik dapat menimbulkan disproporsionalitas yang tinggi, tetapi pada sisi lainnya memaksa partai-partai melakukan fusi untuk memenangkan satu distrik pemilihan. Sekalipun sistem distrik dinyatakan banyak mengalami disproporsional, dilihat dari presentase suara yang tidak terwakili dalam satu distrik, tetapi pada sisi lainnya terpilihnya seorang wakil membentuk emosional yang kuat dengan konstituen daerah pemilihnya, sebab bagaimanapun keberadaaannya merupakan wakil dari distriknya.

Secara umum model sistem pemilu dikembangkan dari dua bentuk sistem pemilu yang sudah umum dikenal yaitu sistem proportional representative (PR) dan sistem plurality/majority (distrik). Negara menggunakan sistem pemilu dengan beberapa pertimbangan antara lain berkaitan dengan kepentingan dan kecocokan kondisi negara tersebut. Pada kondisi tertentu setiap pilihan penggunaan sistem

\footnotetext{
${ }^{33}$ ibid. [401-403].
} 
pemilu mempertimbangkan aspek representativeness atau keterwakilan politik semua unsur, kelompok dan golongan dalam masyarakat, atau pada penekanan aspek yang lain yaitu untuk mewujudkan pemerintah yang dapat memerintah (governable) atau yang umum dikenal dengan pemerintahan yang efektif. ${ }^{34}$

Tabel 1. Sistem Pemilu di Indonesia (1955- 2019)

\begin{tabular}{|c|c|c|c|c|}
\hline $\begin{array}{l}\text { Kategori } \\
\text { Tahun } \\
\end{array}$ & Dasar Hukum & Kepartaian & Jumlah Parpol & Sistem Pemilihan \\
\hline 1955 & UU 7/1953 & Multi Partai & 29 Parpol & Sistem Proporsional \\
\hline 1971 & UU 15/1969 & Multi Partai & 10 Parpol & $\begin{array}{l}\text { Sistem proporsional } \\
\text { dengan stelsel daftar }\end{array}$ \\
\hline 1977 & UU 4/1975 & $\begin{array}{l}\text { Multi Partai } \\
\text { Sederhana }\end{array}$ & 3 Parpol & $\begin{array}{l}\text { Sistem proporsional } \\
\text { dengan stelsel daftar }\end{array}$ \\
\hline 1982 & UU 2/1980 & $\begin{array}{l}\text { Multi Partai } \\
\text { Sederhana }\end{array}$ & 3 Parpol & $\begin{array}{l}\text { Sistem proporsional } \\
\text { dengan stelsel daftar }\end{array}$ \\
\hline 1987 & UU 1/1985 & $\begin{array}{l}\text { Multi Partai } \\
\text { Sederhana }\end{array}$ & 3 Parpol & $\begin{array}{l}\text { Sistem proporsional } \\
\text { dengan stelsel daftar }\end{array}$ \\
\hline 1992 & UU 1/1985 & $\begin{array}{l}\text { Multi Partai } \\
\text { Sederhana }\end{array}$ & 3 Parpol & $\begin{array}{l}\text { Sistem proporsional } \\
\text { dengan stelsel daftar }\end{array}$ \\
\hline 1997 & UU 1/1985 & $\begin{array}{l}\text { Multi Partai } \\
\text { Sederhana }\end{array}$ & 3 Parpol & $\begin{array}{c}\text { Sistem proporsional } \\
\text { stelsel daftar }\end{array}$ \\
\hline 1999 & UU 3/1999 & Multi Partai & 48 Parpol & $\begin{array}{c}\text { Sistem proporsional } \\
\text { stelsel daftar }\end{array}$ \\
\hline 2004 & UU $12 / 2003$ & Multi Partai & 24 Parpol & $\begin{array}{c}\text { Sistem Proporsional } \\
\text { terbuka }\end{array}$ \\
\hline 2009 & $\begin{array}{l}\text { UU 10/2008 } \\
\text { UU 42/2008 }\end{array}$ & Multi Partai & 38 Parpol & $\begin{array}{c}\text { Sistem Proporsional } \\
\text { terbuka }\end{array}$ \\
\hline 2014 & $\begin{array}{l}\text { UU 8/2012 } \\
\text { UU 15/2011 }\end{array}$ & Multi Partai & 12 Parpol & $\begin{array}{c}\text { Sistem Proporsional } \\
\text { terbuka }\end{array}$ \\
\hline 2019 & UU 7/2017 & Multi Partai & (Proses) & $\begin{array}{c}\text { Sistem Proporsional } \\
\text { terbuka }\end{array}$ \\
\hline
\end{tabular}

Pemilu di Indonesia sejak 1955 sampai dengan yang akan dilaksanakan tahun 2019 masih dipengaruhi oleh sangat kuatnya penggunaan sistem pemilu proporsional. Pemilu dengan sistem proporsional masih dilihat yang paling sesuai bagi Indonesia meski dalam praktiknya dianggap masih banyak menimbulkan masalah. Masalahmasalah tersebut antara lain kualitas anggota legislatif terpilih yang dianggap masih rendah dan anggota legislatif terpilih tidak akuntabel. Kemudian ditambah dengan penggunaan sistem proporsional-multipartai menyebabkan terbentuknya partai

\footnotetext{
${ }^{34}$ Moch. Nurhasim, Fisibilitas Sistem Pemilu Campuran: Upaya Memperkuat Sistem Presidensial Di Indonesia (Lembaga Ilmu Pengetahuan Indonesia 2014).[153].
} 
minoritas. Sebaran kursi di parlemen akan menyulitkan melahirkan satu kekuatan mayoritas yang berfungsi sebagai pendukung kebijakan presiden. ${ }^{35}$

Alasan utama yang sering digunakan kenapa menggunakan sistem proporsional adalah berkaitan dengan tingkat representasi yang tinggi, tidak ada suara yang terbuang, memberikan peluang kepada semua golongan dalam masyarakat (termasuk golongan minoritas) untuk memiliki wakil di parlemen. Sistem pemilu proporsional digunakan untuk mendorong bekerjannya sistem untuk memberikan kesempatan kepada setiap partai peserta pemilu mendapatkan kursi secara proporsional. Sistem pemilu proporsional bukan diperuntukan untuk membatasi jumlah partai di parlemen. Akan tetapi kebaikan sistem ini tidak dipertahankan dan dibatasi dengan Electoral Threshold/ Parlementary Threshold sehingga alasan penggunaan sistem proporsional untuk memberikan kesempatan pada semua pihak tidak dapat diterapkan.

Penerapan sistem pemilu mayoritarian (distrik) dimana "the winner take alls" nampaknya perlu dipertimbangkan sebagai alternatif atas penerapan sistem pemilu proporsional yang selama ini digunakan di Indonesia. Penggunaan sistem distrik diyakini mampu mendorong secara alamiah penyederhanaan partai politik serta peningkatan akuntabilitas calon terpilih. Akan tetapi penerapan sistem mayoritarian/plurality (distrik) dikhawatirkan menyebabkan ketidaknyamanan karena Indonesia adalah negara yang sangat heterogen dan perlu memperhatikan kelompok minoritas.

Untuk mengatasi masalah sistem pemilu di Indonesia maka diperlukan sistem alternatif yaitu Sistem Pemilu Campuran. Sistem pemilu campuran sebagai jembatan dua sistem antara sistem proporsional dan sistem mayoritarian (distrik) dengan mengkombinasikan kebaikan masing-masing sistem. Sistem ini dianggap mampu membenahi kelemahan utama sistem proporsional secara alamiah yaitu untuk rekayasa penciptaan sistem partai mayoritas minimal di parlemen untuk mendukung kebijakan presiden dan untuk memperbaiki akuntabilitas wakil rakyat kepada konstituennya.

${ }^{35}$ ibid. [150]. 
Disisi lain sistem campuran juga menutup kelemahan dari sistem mayoritarian yaitu the winner takes all yaitu dengan tetap menggunakan sistem proporsional untuk mengakomodir kelompok yang heterogen dan minoritas.

Penerapan sistem campuran dilakukan dengan langkah sebagai berikut pertama, daerah pemilihan terbagi atas daerah pemilihan berdasarkan sistem mayoritarian dan daerah pemilihan berdasarkan sistem proporsional. Kedua, Ada dua calon yang ikut dalam pemilu yaitu calon yang maju melalui sistem distrik (mayoritarian) dan calon yang maju menggunakan sistem proporsional. Penerapan Sistem Campuran dapat dijelaskan dalam gambar sebagai berikut:

Tabel 2. Usulan Komposisi Sistem Pemilu Campuran

\begin{tabular}{ccc}
\hline Jumlah Kursi DPR & \multicolumn{2}{c}{ KOMPOSISI } \\
\hline & $\begin{array}{c}\text { Kursi Proporsional } \\
\text { (Tertutup) }(60 \%)\end{array}$ & Kursi Distrik (40\%) \\
575 & 345 Kursi & 230 Kursi
\end{tabular}

Secara teknis sistem campuran dipergunakan sesuai dengan kebutuhan dan dapat diterapkan dengan tetap memperhatikan asas-asas langsung, umum, bebas, rahasia, jujur dan adil, serta untuk mendukung kualitas para legislator dan penataan sistem kepartaian untuk mendukung sistem presidensiil.

Dalam pandangan Aristoteles apa yang adil itu berada di tengah (Doktrin Mesotes) karena situasi yang sangat adil dan sangat tidak adil selalu bersifat ekstrem. Kemudian Aristoteles membedakan moderasi keadilan menjadi 2 (dua) yaitu keadilan umum (Iustitia generalis) dan keadilan khusus (Iustitia particularis/ Iustitia specialis). Dimana keadilan umum adalah keadilan yang berlaku secara umum yang bisa dipahami sebagai semua untuk semua yang belum tentu akan menjadi jelas manakala masuk ke dalam domein individual. ${ }^{36}$ Aristoteles memang mempersoalkan bagaimana manusia harus menilai apa yang adil dan apa yang tidak adil. Dia mengusulkan apa yang dikenal sebagai doktrin Mesotes yang pada pokoknya bertujuan mencari titik tengah di antara dua ekstrem dalam berbagai keadaan karena baginya dunia moral hanya bergerak di antara dua kemungkinan

\footnotetext{
${ }^{36}$ Budiono Kusumohamidjojo, Teori Hukum, Dilema Antara Hukum Dan Kekuasaan (Yrama Widya 2016).[270].
} 
ekstrem: kemaksiatan dan kebajikan. Jika diterapkan dalam praktik, orang dapat menghadapi pilihan seperti ini: Jika kebohongan adalah kemaksiatan, maka kebenaran adalah kebajikan. Tetapi karena sama sekali menghindari yang buruk dan sebaliknya sama sekali melakukan hanya yang baik itu praktis adalah tidak mungkin, seringkali orang berhadapan dengan keharusan untuk mencari jalan tengah. Pada akhirnya, menurut Aristoteles perilaku yang adil adalah titik tengah antara berbuat tidak adil dan menderita ketidakadilan. ${ }^{37}$

Kemudian pendapat tersebut didukung oleh Hans Kelsen dengan prinsip proporsionalitas dimana masing-masing memperoleh apa yang akan ditetapkan sebagai harus berlaku demikian bagi setiap orang. Tetapi siapa yang harus menetapkan bahwa sesuatu itu harus berlaku demikian bagi setiap orang? Di negara demokratis orang berusaha merebut posisi menentukan itu dalam pemilihan umum karena hanya pemenang pemilihan umum yang akan menguasai parlemen dan kemudian menentukan apa yang harus atau tidak boleh bagi orang banyak. ${ }^{38}$

\section{Kesimpulan}

Penataan Sistem Pemilihan Umum untuk Penguatan Sistem Presidensiil di Indonesia dapat dilakukan dengan melakukan perubahan sistem pemilu. Tujuan perubahan untuk menghasilkan partai mayoritas minimal di parlemen untuk mendukung kebijakan presiden serta untuk memperbaiki akuntabilitas wakil rakyat kepada konstituennya yang selama ini menjadi masalah dalam lembaga perwakilan. Sistem pemilu campuran sebagai sistem alternatif yang belum pernah di terapkan di Indonesia yang merupakan kombinasi antara sistem proporsional dan sistem distrik. Sistem ini diyakini mampu menutup kelemahan sistem mayoritarian yaitu the winner takes all dengan tetap menggunakan sistem proporsional untuk mengakomodir kelompok heterogen dan minoritas.

\footnotetext{
${ }^{37}$ ibid. [281].

${ }^{38}$ ibid. [282].
} 


\section{Daftar Bacaan}

\section{Buku}

Amartya Sen, The Idea of Justice (Harvard University Press 2009).

Ayman Ayoub dan Andrew Ellis (ed), Electoral Justice: The International IDEA Handbook (International IDEA).

Budiono Kusumohamidjojo, Teori Hukum, Dilema Antara Hukum Dan Kekuasaan (Yrama Widya 2016).

Daniel E. Branner Jr., Checks and Balances: The Three Branches of the American Government, Volume 1 (Thomson Gale 2005).

Firdaus, Constitutional Engineering (Yrama Widya 2015).

Hans Kelsen, Introduction to The Problems of Legal Theory (Bonnie Litschewski Paulson and Stanley L. Paulson ed, Clarendon Press 1992).

Jimly Asshiddiqie, Format Kelembagaan Negara Dan Pergeseran Kekuasaan Dalam UUD 1945 (FH UII Press 2004).

_- Format Kelembagaan Negara Dan Pergeseran Kekuasaan Dalam UUD 1945 (FH UII Press 2005).

__, Pokok-Pokok Hukum Tata Negara Indonesia Pasca Reformasi (Bhuana Ilmu Populer 2007).

—_, Konstitusi Dan Konstitusionalisme Indonesia (Sinar Grafika 2010).

John Rawls, A Theory of Justice (Harvard University Press 1999).

José Antonio Cheibub, Minority Presidents, Deadlock Situations, and the Survival of Presidential Democracies (Yale University Press).

Joses Antonio Cheibub, Presidentialism, Parliamentarism and Democracy (Cambridge University Press 2007).

Lawrence LeDuc,[et.,al.], Comparing Democracy 3: Elections and Voting in the 21st (Century SAGE Publications 2010).

Mahkamah Konstitusi, Naskah Komprehensif Perubahan Undang-Undang Dasar Negara Republik Indonesia Tahun 1945, Latar Belakang, Proses, Dan Hasil Pembahasan, 1999-2002, Buku V Pemilihan Umum (Edisi Revi, Sekretariat Jenderal dan Kepaniteraan Mahkamah Konstitusi 2010). 
Miriam Budiarjo, Dasar-Dasar Ilmu Politik (Gramedia Pustaka Utama 2008).

Moch. Nurhasim, Fisibilitas Sistem Pemilu Campuran: Upaya Memperkuat Sistem Presidensial Di Indonesia (Lembaga Ilmu Pengetahuan Indonesia 2014).

Moh. Kusnardi dan Harmailly Ibrahim, Pengantar Hukum Tata Negara Indonesia (FHUI 1980).

Saldi Isra, Pergeseran Fungsi Legislasi: Menguatnya Model Legislasi Parlementer Dalam Sistem Presidensial Indonesia (Rajawali Press 2010).

Scott Mainwaring, Presidentialism, Multipartism and Democracy: The Difficult Combination, Comparative Political Studies Vol 26 No. 2 (Sage Publications 1993).

Soewoto Mulyosudarmo, Pembaharuan Ketatanegaraan Melalui Perubahan Konstitusi (Asosiasi Pengajar HTN dan HAN dan In-TRANS 2004).

Veri Junaidi,[et.,al.], Evaluasi Penegakan Hukum Pemilu 2014 (Perludem 2015).

\section{Jurnal}

Juan J. Linz, 'The Perils of Presidentialism' (1990) 1 Journal of Democracy.

Khairul Fahmi, 'Menelusuri Konsep Keadilan Pemilihan Umum Menurut UUD 1945' (2016) 4 Jurnal Cita Hukum.

Retno Saraswati, 'Desain Sistem Pemerintahan Presidensial Yang Efektif' (2012) 4 MMH Jurnal.

\section{Laman}

Djayadi Hanan, 'Memperkuat Presidensialisme Multipartai Di Indonesia: Pemilu Serentak, Sistem Pemilu Dan Sistem Kepartaian' (2017) <http://puskapol. ui.ac.id $>$ accessed 7 November 2018.

\section{Putusan Pengadilan}

Putusan Mahkamah Konstitusi Nomor 14/PUU-XI/2013 Tentang Pengujian Undang-Undang Nomor 42 Tahun 2008 Tentang Pemilihan Umum Presiden dan Wakil Presiden.

HOW TO CITE: Mohammad Syaiful Aris, 'Penataan Sistem Pemilihan Umum yang Berkeadilan Untuk Penguatan Sistem Presidensiil di Indonesia' (2018) 33 Yuridika. 